\title{
Experimental micropedology- A technique for investigating soil carbonate biogenesis along a desert-grassland-forest transect, New Mexico, USA
}

\begin{abstract}
Microedafología experimental - Una técnica para investigar la biogénesis de carbonato en el suelo a lo largo de un transecto desierto-pradera-bosque, Nerw Mexico, USA

Micropedologia experimental - Uma técnica para investigar a biogénese dos carbonatos no solo ao longo de um transecto deserto-pastagem-floresta, Nerw Mexico, USA
\end{abstract}

\section{AUTHORS}

Khormali F. @1

fkhormali@gau.ac.ir

Received: 26.03.2013 | Revised: 25.07.2013 | Accepted: 28.01.2014

\section{Monger C. ${ }^{2}$}

Feng $\mathbf{Y}^{2}$

@ Corresponding Author

${ }^{1}$ Department of Soil Sciences, Faculty of Water and Soil

Engineering. Gorgan University of Agricultural Sciences and Natural Resources. Gorgan, Iran, 49138-15739.

${ }^{2}$ Department of Plant and Environmental Sciences. New Mexico State University. Las Cruces, NM, 88003, USA.

\begin{abstract}
Manipulative experiments - characterized by comparing treatments to controls - are widespread in scientific investigations. This study uses experimental micropedology to investigate whether soil microbes precipitate carbonate if a liquid growth-medium is applied to soil in situ. This was undertaken using apparatuses designed to (1) obtain micromorphological images of biogenic carbonate on microscope slides, (2) to quantify carbonate formation in fiberglass cloths, and (3) to measure associated carbonisotope fractionations. The apparatuses were buried and harvested at monthly intervals from December 2010 to June 2011. The study was conducted along an ecological transect in New Mexico, USA, at three sites: a low-elevation desert $\left(\mathrm{C}_{3}\right.$ shrubs), an intermediate-elevation steppe $\left(\mathrm{C}_{4}\right.$ grasses), and a high-elevation forest $\left(\mathrm{C}_{3}\right.$ conifers). In addition to comparing bioclimatic zones, the effect of parent material was also tested using paired limestone and igneous soils at each site. Soil samples in their natural state and inserted microscope slides were analyzed with binocular, petrographic, and scanning electron microscopy equipped with an x-ray microanalyser (EDS), and the fiberglass traps were analyzed with $\mathrm{x}$-ray diffraction and a mass spectrometer for carbon concentrations and isotope ratios. Naturally occurring calcified microbes were found at each site in the form of calcified hyphae, needle fiber, and calcified root hairs, with the exception of the forest site on igneous parent material. Liquid growth medium induced microbial calcification regardless of whether the vegetation was desert shrubs, grassland, or forest, and regardless of whether the parent material was igneous or limestone. Thus, the ability of soil microorganisms to biomineralize carbonate when supplied with liquid growth medium in situ is a phenomenon that crosses biomes and is not limited to microbes endemic to either limestone or igneous parent material.
\end{abstract}

\section{RESUMEN}

Los experimentos manipulativos, caracterizados por comparar tratamientos con experiencias control, se utilizan ampliamente en las investigaciones cientificas. Este estudio aplica la microedafología experimental para investigar si los microorganismos del suelo precipitan carbonato al aplicar in situ un medio de crecimiento líquido al suelo. Esto se llevó a cabo utilizando aparatos diseñados para (1) obtener imágenes micromorfológicas de carbonato biogénico sobre láminas delgadas, (2) cuantificar la formación de carbonato sobre telas de fibra de vidrio, y (3) medir fraccionamientos isotópicos de carbono asociados. Los aparatos fueron enterrados en el suelo y recogidos en intervalos mensuales desde diciembre de 2010 hasta junio de 2011. El estudio se realizó a lo largo de un transecto ecológico en New Mexico, USA, en tres localizaciones: un desierto de relieve suave (arbustos $C_{3}$ ), una pradera de relieve intermedio (pastos $C_{4}$ ) y un bosque de alto relieve (coniferas $C_{3}$ ). Además de comparar las distintas zonas bioclimáticas también se analizó el efecto del material parental estudiando suelos sobre rocas carbonatadas 
e ígneas en cada lugar. Las láminas delgadas se analizaron con microscopia binocular, petrográfica y electrónica de barrido equipada con un mincroanalizador de rayos $X(E D S)$, y las trampas de fibra de vidrio se analizaron mediante difracción de rayos $X$ y un espectrómetro de masas para obtener las concentraciones de carbono y las razones isotópicas. En cada localización se encontraron microorganismos calcificados existentes de forma natural en forma de micelios calcificados filamentosos y pelos de raíces calcificados, con la excepción del lugar sobre material ígneo en la zona de bosque. El medio de crecimiento líquido indujo la calcificación microbiana independientemente del tipo de vegetación o de material parental. Asi, la habilidad de los microorganismos del suelo para biomineralizar carbonato mediante la aportación in situ de un medio de crecimiento líquido es un fenómeno transversal independiente del bioma y que no está limitado a microorganismos endémicos de materiales calizos o ígneos.

\section{RESUMO}

Os ensaios de manipulação - caracterizados pela comparação dos tratamentos com as testemunhas (controlos) estão largamente difundidos em investigação científica. Este estudo utiliza a micro pedologia experimental para investigar se os microrganismos do solo precipitam carbonato quando se aplica um meio de crescimento líquido ao solo in situ. Este trabalho foi levado a cabo utilizando dispositivos projetados para (1) obter imagens micromorfológicas de carbonato biogénico em lâminas finas, (2) quantificar a formação de carbonato em tecidos de fibra de vidro, $e$ (3) medir o fracionamento isotópico de carbono associado. Os dispositivos foram enterrados no solo e recolbidos com intervalos mensais de dezembro de 2010 até junho de 2011. O estudo foi realizado ao longo de um transecto ecológico no Novo México, EUA, em três locais: um deserto de relevo suave (arbustos C3), uma planície de relevo intermédio (gramineas C4) e uma floresta de alto relevo (coníferas C3). Além de comparar áreas bioclimáticas foi também analisado o efeito do material parental estudando em cada local solos localizados sobre rochas carbonatadas e rochas magmáticas. As lâminas finas foram analisadas por microscopia binocular e petrográfica e microscopia eletrónica de varrimento equipada com um micro analisador de raios- $X(E D S)$, e os tecidos de fibra de vidro foram analisados por difração de raios $X$ e espectrometria de massa para obter concentraçôes de carbono e relaçôes isotópicas. Em cada local foram encontrados microrganismos calcificados formados naturalmente em forma de micélios calcificados filamentosos e pelos de raízes calcificados, com exceção do local sobre material ígneo na zona de floresta. O meio de crescimento líquido induziu à calcificação microbiana, independentemente do tipo de vegetação ou material parental. Assim, a capacidade dos microrganismos do solo para biomineralizar carbonato mediante o fornecimento no local de um meio de crescimento líquido é um fenómeno transversal independente do bioma e não está limitado aos microrganismos endémicos de materiais calcários ou ígneos.

\section{Introduction}

Micropedology, like pedology, studies soil as a natural phenomenon, taking into account its composition, distribution and method of formation (FitzPatrick 1972, 1993). Micropedology and pedology differ from other disciplines of soil science because they work with undisturbed soil in its natural environment. Still, soil samples must be taken to the lab and "a soil sample really is not soil" (Kubiëna 1970). Moreover, fabric analysis using petrographic methods, like profile analysis using field methods, is a descriptive science (Brewer 1964; Bullock et al. 1985; Stoops 2003). This study takes a manipulative-experimental approach used in many agricultural, forestry, and environmental studies by comparing treatments with controls. Rather than taking samples to the lab, it brings the microscope slides to the natural soil in the field. It adds liquid growth medium to soil microhabitats to stimulate indigenous microbial populations. The focus of this study (i.e., the response variable of this manipulative experiment) is soil carbonate. 
Soil carbonate is an important soil component because it serves as an indicator of landscape stability and paleoclimate, it affects nutrient availability, and it has implications for carbon sequestration (Gile et al. 1966; Cerling 1984; Monger et al. 2011). Soil carbonate has been traditionally viewed as a soil mineral, which, of course, it is. The problem with this viewpoint, however, is that it considers soil $\mathrm{CaCO}_{3}$ to be geological, not biological. That is, carbonate formation and dissolution, like other soil minerals, are governed by abiotic physicochemical processes (Marion et al. 1985; Marion et al. 2008; Breecker et al. 2009; Hirmas et al. 2010; Schlesinger et al. 2009). Without invoking biomineralization processes, many authors have traditionally, and successfully, modeled the precipitation and dissolution of calcium carbonate in soil using the classical equation below:

$$
\mathrm{Ca}^{2+}+2 \mathrm{HCO}_{3}^{-} \rightarrow \mathrm{CaCO}_{3}+\mathrm{CO}_{2}+\mathrm{H}_{2} \mathrm{O}
$$

Soil carbonate does, however, have a long history of investigations that indicates a biological origin, at least in part. In an early study on the topic, Krumbein (1968) identified bacteria in a calcrete from Israel that could precipitate calcite when cultured in solid media. Boquet et al. (1973) found that many strains of bacteria, including Salmonella spp., Bacillus pumilus, and Pseudomonas aeruginosa, could form calcite crystals in 1 to 20 days on a medium containing calcium acetate. Biomineralization of calcretes and needle fiber calcite as a biologicallyproduced mineral have been recognized since the 1990s (Verrecchia 1990; Verrecchia and Verrecchia 1994). Field studies have provided evidence for organic formation of calcretes (Goudie 1996), while micromorphology studies have revealed calcified hyphae in petrocalcic horizons of limestone soils in central Texas (Wilding et al. 1997). Soil microorganisms were also found to be involved in calcite precipitation in a typical desert soil near Las Cruces, New Mexico where fossilized remains of calcified fungal hyphae are abundant (Monger et al. 1991). In lab experiments, soil bacteria and fungi precipitated calcite when cultured on a Ca-rich medium. In an experiment where soil columns were irrigated with Ca-rich solutions, calcite formed in soils containing soil microorganisms, but no calcite formed in sterile soils. Thus, calcic and petrocalcic horizons are not simply the result of inorganic precipitation of calcite.

More recently, Burford et al. (2006) investigated the roles of fungi in the transformation of limestone and provided direct experimental evidence of fungal-mediated carbonate precipitation when cultured under low nutrient conditions on a solid limestone substrate. Their results revealed calcite biomineralization by two strains of fungi grown in buffered neutral to alkaline conditions, saturated with respect to carbonate.

Verrecchia et al. (2006) emphasize a key role of fungi in the oxalate-carbonate pathway and its importance as a major global carbon sink. In a well-buffered neutral to alkaline environment containing sufficient amounts of $\mathrm{Ca}^{2+}, \mathrm{Mg}^{2+}$, some of the $\mathrm{CO}_{2}$ will be transformed into carbonate, which will precipitate with the appropriate cations. Thus, precipitation of $\mathrm{CaCO}_{3}$ on fungal hyphae could be the result of fungal metabolic processes, and also a consequence of bacterial oxalate degradation (Verrecchia et al. 1990; 2006). Similarly, Cailleau et al. (2011) found that calcite biomineralization in trees is related to the oxalate oxidation in soil. The consequence of this oxidation is the presence of carbonate ions in the soil solution pumped through the roots, leading to preferential mineralization of the roots and the trunk base.

Worldwide, several SEM studies of calcareous terrestrial deposits have shown the importance of soil microorganisms in biomineralization of carbonate. Such studies have revealed fossilized communities of soil microorganisms in samples from the Florida Keys (Kahle 1977), the western Mediterranean area (Klappa 1979), southern Australia (Phillips et al. 1987), and the British West Indies (Jones 1988). In the southern High Plains of Texas, SEM and thin-section analyses revealed calcified filaments and Microcodium structures in petrocalcic horizons (Chitale 1986). These calcified filaments are similar in size and shape to filaments that Phillips et al. (1987) and Jones (1988) attributed to calcified fungal hyphae. Monger and Adams (1996) observed the fossilized remains of calcified 


\section{Materials and Methods}

fungal hyphae and Microcodium structures in petrocalcic horizons of Nevada. Moreover, because pedogenic carbonates provide important evidence about paleoclimate and because organisms generally prefer lighter isotopes, it remains to be determined if microbial biomineralization causes fractionation of carbon isotopes (Cerling 1984; Quade et al. 1995; Monger et al. 2009).

Using experimental micropedology, this study addresses questions concerned with how widespread carbonate biomineralization is in different, but adjacent, bioclimatic zones and parent materials. It focuses on the possibility that indigenous microorganisms can be manipulated to generate pedogenic carbonate in situ. If so, does the type of ecosystem make a difference? Does parent material make a difference? Do microbes in these different ecosystems fractionate carbon isotopes differently? To answer these questions the following micropedology field experiment was conducted.

\subsection{Bioclimatic setting}

Sample sites along an elevation transect in southern New Mexico were chosen that are located in a desert shrubland in the Chihuahuan Desert, a grassland in a neighboring semiarid steppe, and a forest in the adjacent sub-humid mountains (Figure 1). The desert shrubs use the $\mathrm{C}_{3}$ photosynthetic pathway, the grasses use the $\mathrm{C}_{4}$ pathway, and the conifers use the $\mathrm{C}_{3}$ pathway, and are thus distinguishable by their isotopic signatures (Cerling 1984). The desert site is at an elevation of $1318 \mathrm{~m}$, has a mean annual max temperature of $26^{\circ} \mathrm{C}$, and a mean annual rainfall of $200 \mathrm{~mm}$. The grassland site is at an elevation of $1681 \mathrm{~m}$, has a mean annual max temperature of $23^{\circ} \mathrm{C}$, and a mean annual rainfall of $300 \mathrm{~mm}$. The forest site is at an elevation of $2300 \mathrm{~m}$, has a mean annual max temperature of $17^{\circ} \mathrm{C}$, and a mean annual rainfall of $560 \mathrm{~mm}$. Greater than 50 percent of the precipitation comes in the summer months as monsoonal rains in



Figure I. Location of study sites and comparison of their relative elevations. Mean annual temperatures and precipitation are given in the text. The general location of the study area is shown in reference to the distribution of soil inorganic carbon in the United States (Guo et al. 2006). 
July, August, and September (Gile et al. 1981). The soil moisture and temperature regimes, as defined in Soil Taxonomy (Soil Survey Staff 1999), range from aridic thermic at the desert site, ustic-aridic thermic at the grassland site, and ustic mesic at the forest site. An extended drought occurred during the period in which this experiment was conducted, so the study area received little, if any, rainfall. For example, only $5 \mathrm{~mm}$ was recorded at the desert site for the duration of this study (Dec 2010 to June 2011), which was carried out based on the first-author's sabbatical visit.

Vegetation at the desert site is dominated by creosotebush (Larrea tridentata) and ratany (Krameria parvifolia), with scattered grasses (Aristida and Bouteloua) and cacti (Opuntia). The steppe grassland site is dominated by black grama (Bouteloua eriopoda), while the forest site is dominated by conifers, mainly ponderosa pine (Pinus ponderosa), alligator juniper (Juniperus deppeana), and pinyon pine (Pinus edulis), with scattered gamble oak (Quercus gambelii) (DickPeddie 1993).
Each of the three study sites were located in areas where soils formed in igneous parent materials were adjacent to soils formed in limestone parent materials. At each site the studied soils were within 200 meters of each other to minimize differences in morphology and genesis of soils that can occur within short distances (Wilding et al. 2001). Soil pits and rock types were described, sampled, and classified following the terminology described by Schoeneberger et al. (2012) (Table 1).

Profiles of soils at the desert sites are shown in Figure 2. Both soils formed in alluvium. The igneous alluvium is from Tertiary rhyolite of the Soledad formation in the Organ Mountains to the east (Seager et al. 1987). The limestone alluvium is from the Permian Hueco formation from Tortugas Mountain to the south. The primary difference between the morphology of the desert soils is an argillic horizon and petrocalcic horizon in the igneous soil, and calcic horizon in the limestone soil. The igneous soil is associated with a geomorphic surface that is older than the adjacent limestone soil, which

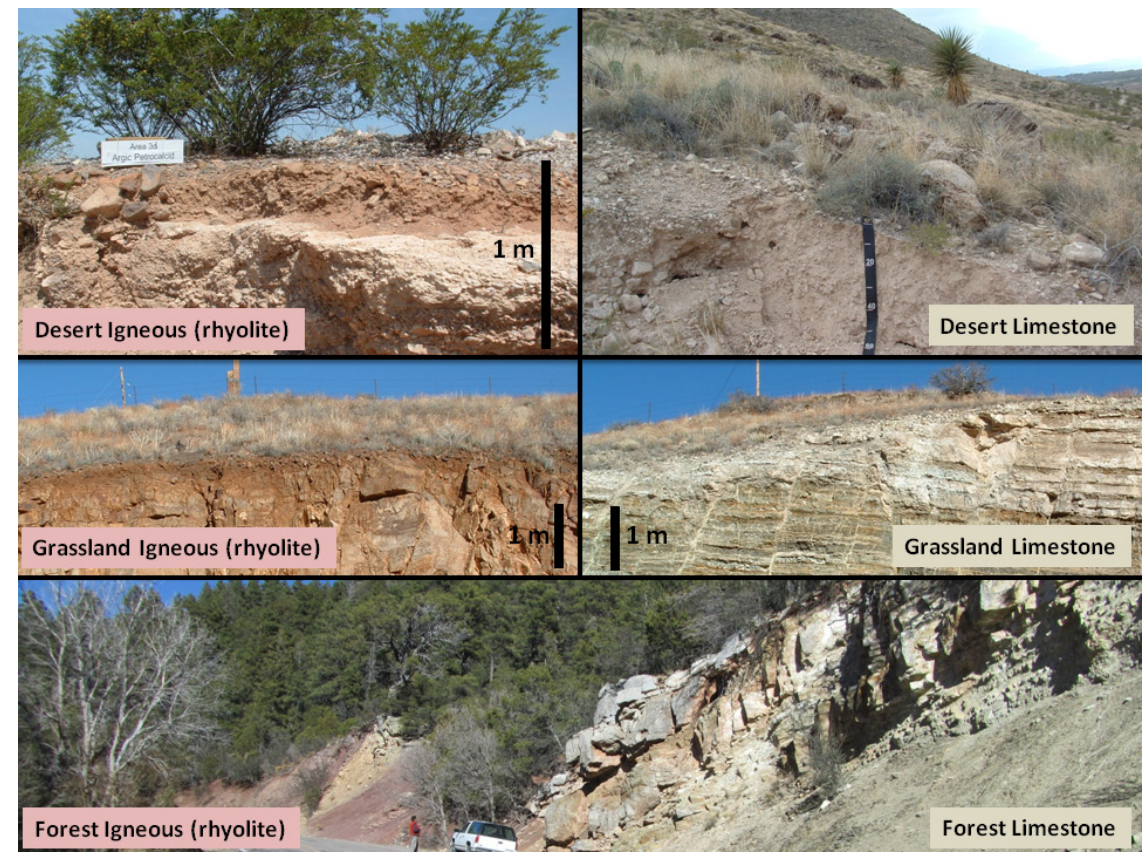

Figure 2. Photographs of soils profiles in the desert (top), grassland (middle), and forest (bottom). Each pair is with 200 meters of each other so that differences in the soil forming factors could be minimized. 
Table 1. Morphological, geomorphic, and vegetative characteristics of the study sites

\begin{tabular}{|c|c|c|c|c|c|}
\hline Site/Horizon & Depth cm & $\begin{array}{l}\text { Textural } \\
\text { Class }\end{array}$ & $\begin{array}{l}\text { Carbonate } \\
\text { Stages }\end{array}$ & Carbonate Forms $^{\dagger}$ & $\begin{array}{l}\text { Landform/ } \\
\text { Material }^{\ddagger}\end{array}$ \\
\hline $\begin{array}{l}\text { Desert Igneous, Argic } \\
\text { Petrocalcid }\end{array}$ & & & & & $\begin{array}{l}\text { Fan-Piedmont/ } \\
\text { Alluvium }\end{array}$ \\
\hline Ak & $0-5$ & sandy loam & Stage I & filaments & \\
\hline Btk & $6-28$ & $\begin{array}{l}\text { sandy clay } \\
\text { loam }\end{array}$ & Stage I & filaments & \\
\hline Bkkm & $28-43$ & sandy loam & Stage IV & laminar/plugged & \\
\hline $\mathrm{Bk}$ & $43-64$ & sandy loam & Stage III & plugged horizon & \\
\hline $\mathrm{Ck}$ & $64-79$ & loam & Stage I & pebble coatings & \\
\hline $\begin{array}{l}\text { Desert Limestone, } \\
\text { Typic Haplocalcid }\end{array}$ & & & & & $\begin{array}{l}\text { Fan-Piedmont/ } \\
\text { Alluvium }\end{array}$ \\
\hline Ak & $0-10$ & sandy loam & Stage I & filaments & \\
\hline Bkk1 & $10-30$ & sandy loam & Stage III & plugged horizon & \\
\hline Bkk2 & $30-100$ & sandy loam & Stage III & plugged horizon & \\
\hline $\begin{array}{l}\text { Grassland Igneous, } \\
\text { Ustic Haplargid }\end{array}$ & & & & & $\begin{array}{l}\text { Hill Backslope/ } \\
\text { Residuum }\end{array}$ \\
\hline A & $0-8$ & loam & - & - & \\
\hline Btk & $8-20$ & clay loam & Stage I & pebble coatings & \\
\hline Rtk & $20-300$ & - & Stage I & joint fillings & \\
\hline $\begin{array}{l}\text { Grassland Limestone, } \\
\text { Ustic Haplocalcid }\end{array}$ & & & & & $\begin{array}{l}\text { Hill Backslope/ } \\
\text { Residuum }\end{array}$ \\
\hline A & $0-10$ & silt loam & - & none & \\
\hline $\mathrm{Bk}$ & $10-20$ & silt loam & Stage II & coatings/masses & \\
\hline Crk & $20-50$ & - & Stage II & coatings/masses & \\
\hline $\mathrm{Rk}$ & $50-300$ & - & Stage II & joint fillings & \\
\hline $\begin{array}{l}\text { Forest Igneous, } \\
\text { Typic Haplustalf }\end{array}$ & & & & & $\begin{array}{c}\text { Mountain Backslope } \\
\text { Colluvium }\end{array}$ \\
\hline A & $0-20$ & sandy loam & - & - & \\
\hline $\mathrm{Bt}$ & $20-50$ & clay loam & - & - & \\
\hline $\mathrm{Cr}$ & $50-150$ & - & - & - & \\
\hline $\mathrm{R}$ & $150-300$ & - & - & - & \\
\hline $\begin{array}{l}\text { Forest Limestone, } \\
\text { Typic Calciustept }\end{array}$ & & & & & $\begin{array}{c}\text { Mountain Backslope } \\
\text { Colluvium }\end{array}$ \\
\hline A & $0-20$ & silt loam & - & - & \\
\hline $\mathrm{Bk}$ & $20-60$ & silt loam & Stage I & pebble coatings & \\
\hline Crk & $60-200$ & - & Stage I & ped coatings & \\
\hline Rk & $200-300$ & - & Stage I & joint fillings & \\
\hline
\end{tabular}

† Carbonate stages and forms from Gile et al. 1966 and Schoeneberger et al. 2012.

‡ Landforms from Peterson 1981. 
explains why one has a petrocalcic horizon (the older) and the other does not (Gile et al. 1981). The igneous soil is classified as an Argic Petrocalcid and the limestone soil as a Typic Haplocalcid (Gile et al. 2003).

Soils at the grassland site are formed in bedrock residuum on backslopes of hills. The igneous and limestone bedrock are juxtaposed along a fault. The igneous rock is Tertiary rhyolite and the limestone is Cambrian in age (New Mexico Bureau of Geology and Mineral Resources 2003). The A horizons in the grassland sites are thicker and more distinct than A horizons at the desert sites. Another difference is less pedogenic carbonate in the igneous soil. The igneous soil at the grassland site is an Ustic Haplargid while the neighboring limestone soil is an Ustic Haplocalcid (Figure 2).

The forest soils also have Tertiary volcanic rocks juxtaposed with limestone along a fault; however, these limestones are Pennsylvanian to Mississippian in age. No pedogenic carbonate is apparent in the igneous soil forest soil, unlike its limestone neighbor (Table 1). The $\mathrm{pH}$ values of all horizons in the desert and grassland soils range from about 7.8 to 8.3 (Gile et al. 1981). Forest soils in New Mexico at elevations of 2300 meters typically have $\mathrm{pH}$ values ranging from 7.2 to 7.8 (Folks 1975). The igneous soil at the forest site formed in colluvium and is classified as a Typic Haplustalf on a mountain blackslope. The limestone soil is a Typic Calciustept formed in colluium on an adjacent mountain backslope.

\subsection{Experimental design}

This study was designed to take growth media to the field soil in order to observe if carbonate biomineralization occurs in situ, and whether ecosystems and parent materials are factors that impact carbonate formation. To achieve this, we designed an apparatus that could be buried in soils, deliver a liquid growth medium, and then be retrieved to observe biomineralization. The apparatus consists of a sterile vial into which a liquid medium was poured, two nylon wicks containing fiberglass cloth sown between the wicks, and an attached microscope slide (Figure 3). This design combined micromorphology with the ability to measure the amount of biogenic carbonate generated in the fiberglass cloth, which could be measured by dry combustion of the total carbon minus the organic carbon. Using a mass spectrometer attached to an elemental analyzer, carbon isotopes could also be measured. Moreover, the properties of biomineralization could be observed by attaching a microscope slide to the wicks.



Figure 3. Apparatus used to deliver liquid growth medium to soil in order to observe in situ carbonate biomineralization on the microscope slide with a petrographic microscope. The fiberglass cloth enclosed between nylon wicks provides a means to measure carbonate and its $\delta^{13} \mathrm{C}$ values with an elemental analyzer attached to a mass spectrometer. 
The apparatus was inserted $10 \mathrm{~cm}$ into the soil with the glass slide extending to $15 \mathrm{~cm}$ (Figure 3), which was a depth that ensured the apparatus was protected from temperature extremes, animals, and erosion. This depth resulted in the slide being in the upper Bk or Bt horizons. Deeper depths would have made it more difficult to retrieve and replace the apparatuses. The growth medium was the "B4" medium which consists of $2.5 \mathrm{~g}$ calcium acetate, $4.0 \mathrm{~g}$ yeast extract, $15.0 \mathrm{~g}$ agar, and $10.0 \mathrm{~g}$ glucose per $1000 \mathrm{ml}$ of distilled water, with the $\mathrm{pH}$ adjusted to 8.0 with $\mathrm{NaOH}$ (Boquet et al. 1973). We used a liquid form which consisted of the same ingredients but without the agar. This growth medium was autoclaved and taken to the field in a sealed sterile container. Likewise, to minimize the possibility of contamination, all apparatuses were sealed in plastic bags from the time of their construction in the lab until they were opened in the field. Growth medium was poured into each apparatus just prior to inserting them in the 10 $\mathrm{cm}$ hole. The liquid medium then moved through the wick and into the dry soil.

In December 2010, six apparatuses were installed at each site. These are referred to as "cumulative" samples because one of the six was harvested one month after installation, a second two months after installation, a third three months afterwards, and so forth until all six apparatuses were harvested by June. A second set of apparatuses were installed monthly and are referred to as "increment" samples. In this case, one apparatus was placed in the soil in January and harvested in February when another apparatus was put in the ground and harvested in March, and so forth until the last apparatus was harvested in June.

To serve as controls, apparatuses filled with water instead of B4 medium were buried and harvested in monthly intervals. Also to serve as controls, bare microscope slides were buried and harvested at monthly intervals. For each site, a total of 20 slides had been inserted into the soil and harvested by the end of the experiment. No statistical significance was applied to differences found among the sites because of the low sample size.

\subsection{Biomineralization features}

Features of biomineralization that occur naturally in soil, such as calcified roots and mycelia, were investigated in the field using a hand lens. At the microscopic scale, these features were viewed in the lab with a binocular microscope and with a scanning electron microscope (SEM) with an energy dispersive $x$-ray microanalysis EDS system (Hitachi, S-3400N Type II, Pleasanton, CA).

Biomineralization on the treated and control microscope slides were observed for each slide with a binocular microscope followed by observation in both plane- and crossedpolarized light using a petrographic microscope at $40 x$ and $100 x$ magnification. Carbonate was identified by its birefringence at a thickness from $4 \mu \mathrm{m}$ to about $30 \mu \mathrm{m}$. Carbonate was also identified by spot-checking with applications of $1 \mathrm{M} \mathrm{HCl}$ and observing effervescence in combination with elemental analysis with the scanning electron microscope. Based on these observations, a table documenting "presence or absence" was created. Carbonate formation in the fiberglass and on roots and hyphae was checked with x-ray diffraction (Rigaku MiniFlex). The fiberglass samples were attached to XRD sample holders using drops of deionized water that, after the water dried, held the samples firmly enough to the holders that they could be analyzed with the instrument.

The amount of carbonate produced in the fiberglass cloth as inorganic carbon, and its $\delta^{13} \mathrm{C}$ values, were measured using an elemental analyzer attached to a continuous-flow isotope ratio mass spectrometer (Micromass, Waters, Inc). This was determined by weighing the fiberglass samples with a microbalance and placing them in tin capsules that were inserted into the autosampler on the elemental analyzer. In order to differentiate organic carbon from inorganic carbon, splits of each sample were made. One split was analyzed for total carbon. The other split was analyzed for organic carbon after immersing the fiberglass in a solution of $1 \mathrm{M} \mathrm{HCl}$ until effervescence ceased. Inorganic carbon was calculated by subtracting organic carbon from total carbon. 
Isotopic determinations were made on several natural vegetation, soil organic, and soil inorganic carbon samples (Table 2) using the following process (Weems and Monger, 2012). The fraction of carbon in the soil organic matter derived from $\mathrm{C}_{4}$ plants $\left(F_{\mathrm{C}_{4}}\right)$ was estimated by the equation (Boutton et al. 1999):

$$
F_{C 4}=\frac{\delta_{\text {SAMPLE }}-\delta_{C 3}}{\delta_{C 4}-\delta_{C 3}}
$$

Table 2. Isotopic values for vegetation and soil samples at the study sites

\begin{tabular}{|c|c|c|c|}
\hline Site/Sample & Material & $\delta^{13} \mathrm{C}$ & $\% \mathrm{C}^{\ddagger}$ \\
\hline \multicolumn{4}{|l|}{ Desert Igneous } \\
\hline Larrea tridentata & shrub/leaves and stems & $-25 \%$ & \\
\hline Btk horizon $(6-28 \mathrm{~cm})$ & soil organic matter & $-21 \%$ & 34 \\
\hline Btk horizon $(6-28 \mathrm{~cm})$ & carbonate filaments & $-12 \%$ & 0 \\
\hline Bkkm horizon(28-43 cm) & organics in petrocalcic & $-16 \%$ & 82 \\
\hline Bkkm horizon(28-43 cm) & carbonate in petrocalcic & $-3 \%$ & 64 \\
\hline \multicolumn{4}{|l|}{ Desert Limestone } \\
\hline Acacia greggii & shrub/leaves and stems & $-26 \%$ & \\
\hline Aristida divaricata & grass/leaves and stems & $-14 \%$ & \\
\hline Bkk1 (10-30 cm) & soil organic matter & $-16 \%$ & 82 \\
\hline Bkk1 (10-30 cm) & carbonate in calcic horizon & $-7 \%$ & 36 \\
\hline \multicolumn{4}{|l|}{ Grassland Igneous } \\
\hline Bouteloua eriopoda & grass/leaves and stems & $-15 \%$ & \\
\hline A horizon $(0-8 \mathrm{~cm})$ & soil organic matter & $-15 \%$ & 91 \\
\hline A horizon $(0-8 \mathrm{~cm})$ & disseminated carbonate & $-5 \%$ & 50 \\
\hline Btk horizon $(8-20 \mathrm{~cm})$ & soil organic matter & $-14 \%$ & 100 \\
\hline Btk horizon $(8-20 \mathrm{~cm})$ & carbonate coatings & $-1 \%$ & 79 \\
\hline \multicolumn{4}{|l|}{ Forest Igneous } \\
\hline Pinus edulis & needles and stems & $-26 \%$ & \\
\hline A horizon $(0-20 \mathrm{~cm})$ & soil organic matter & $-22 \%$ & 27 \\
\hline \multicolumn{4}{|l|}{ Forest Limestone } \\
\hline A horizon $(0-20 \mathrm{~cm})$ & soil organic matter & $-25 \%$ & 0 \\
\hline A horizon $(0-20 \mathrm{~cm})$ & disseminated carbonate & $-13 \%$ & 0 \\
\hline Crk horizon $(60-200 \mathrm{~cm})$ & soil organic matter & $-23 \%$ & 18 \\
\hline Crk horizon $(60-200 \mathrm{~cm})$ & carbonate coatings & $-9 \%$ & 21 \\
\hline
\end{tabular}

$\ddagger$ Theoretical percent of C4 vegetation based on equations 1 and 2 . 
where $\delta_{\text {SAMPLE }}$ is the $\delta^{13} \mathrm{C}$ of the bulk soil sample, $\delta_{C 3}$ is the average $\delta^{13} \mathrm{C}$ value of the $\mathrm{C}_{3}$ components, $\delta_{\mathrm{C}}$ is the average $\delta^{13} \mathrm{C}$ value of the $\mathrm{C}_{4}$ components. End-member values of $-25 \%$ were used for $\mathrm{C}_{3}$ plants and $-14 \%$ ofor $\mathrm{C}_{4}$ plants (Boutton et al. 1999). The $\mathrm{C}_{4}$ fraction based on pedogenic carbonate was estimated by the equation:

$$
F_{C 4}=\frac{\delta_{\text {SAMPLEpedcarb }}-\delta_{C 3 \text { pedcarb }}}{\delta_{C 4 \text { pedcarb }}-\delta_{C 3 \text { pedcarb }}}
$$

where $\delta_{\text {SAMPLEPed Carb }}$ is the $\delta^{13} \mathrm{C}$ of the carbonate in the soil sample, $\delta_{\text {Cзреd carb }}$ is the average $\delta^{13} \mathrm{C}$ value derived from the $C_{3}$ components, $\delta_{\text {C4ped carb }}$ is the average $\delta^{13} \mathrm{C}$ value derived from the $C_{4}$ components. End-member values of $-12 \%$ o were used for $\mathrm{C}_{3}$ plants and $+2 \%$ ofor $\mathrm{C}_{4}$ plants (Quade et al. 1995). The amount of fractionation caused by microbial precipitation of carbonate was to be determined against the $\delta^{13} \mathrm{C}$ value of the $\mathrm{B} 4$ medium measured to be $-14 \%$.

\section{Results and Discussion}

\subsection{Natural biomineralization features}

Natural biomineralization in the form of calcified fine roots and mycelia could be observed in all soil profiles with a 10x hand lens, except for the igneous forest soil. These biological forms were most easily observed on the surfaces of coarse fragments. At the microscopic scale, various combinations of calcified root hairs, fungal hyphae, and needle fiber calcite were identified in all soil profiles with both the binocular scope and SEM (Figure 4), except for the igneous soil at the forest site. A chemical spectrum was made of the needle fiber at the grassland site (Figure 5) and indicates calcite. X-ray diffraction was used to analyze the calcified roots and fungal hyphae at the forest limestone site to check for $\mathrm{Ca}$ oxalate, but only calcite was revealed (Figure 6).
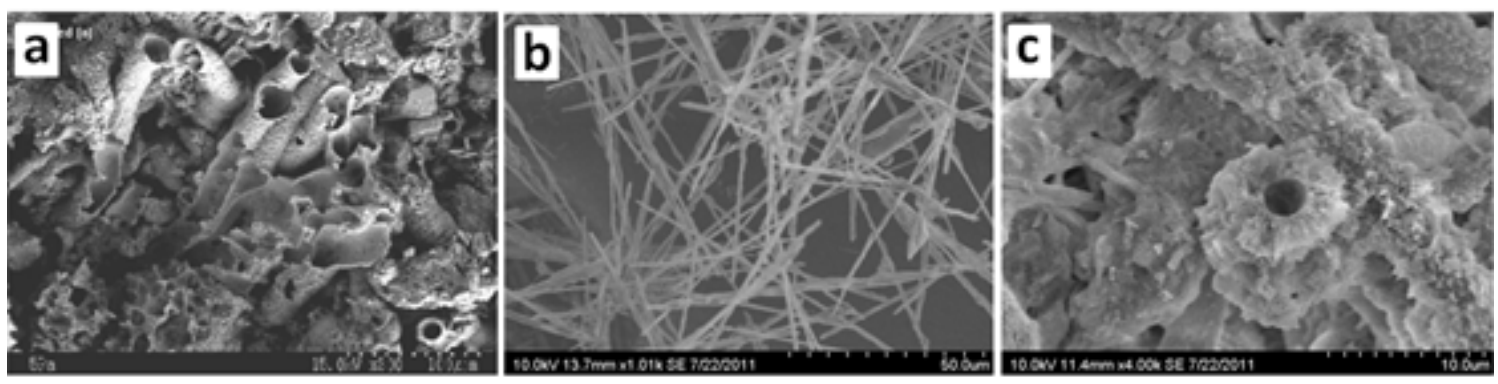

Figure 4. Examples of natural biomineralized forms of carbonate. (a) Calcified root hairs at the desert site with limestone parent material. (b) Needle-fiber at the grassland site. (c) Calcified fungal hyphae at the forest limestone site.

\subsection{Biomineralization on microscope slides}

Microscopic analysis of buried microscope slides attached to the nylon wicks revealed the following. Calcified fungal hyphae were the only form of biomineralization discernible with the binocular and petrographic microscopes. If bacterial biomineralization occurred, it was too small to document with light microscopy. Fungal calcification occurred as linear crystalline segments along the hyphae (Figure 7). The hyphae were most abundant along the sides and back of the microscope slides. The fiberglass cloth was analyzed by $x$-ray diffraction to test for calcite, but no calcite peaks were discernible within the broad peak produced by the amorphous glass. Neither was calcium oxalate detected by XRD. The amount of carbonate generated in the fiberglass was too small to obtain ${ }^{13} \mathrm{C} /{ }^{12} \mathrm{C}$ ratios with the mass spectrometer. 


\section{Full scale counts: 979}

1000

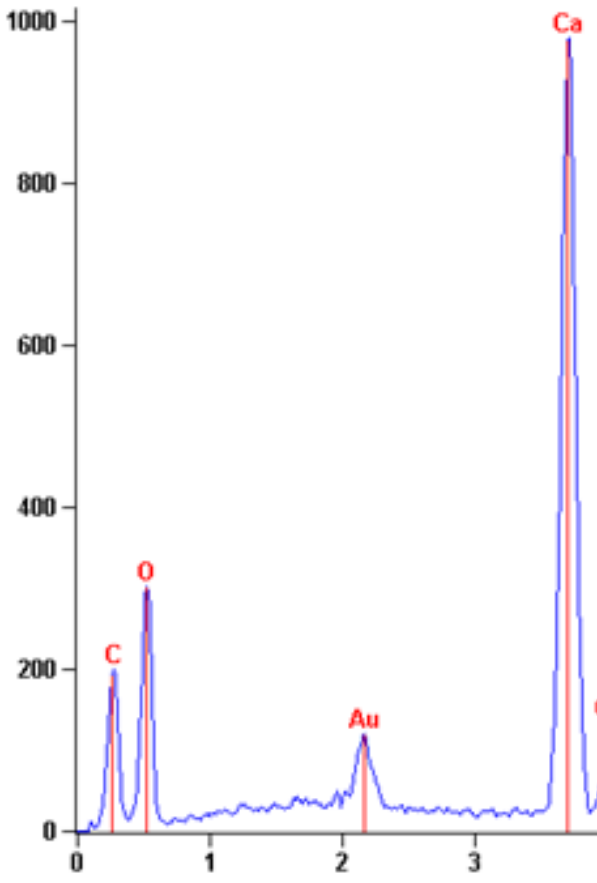

072211(22)

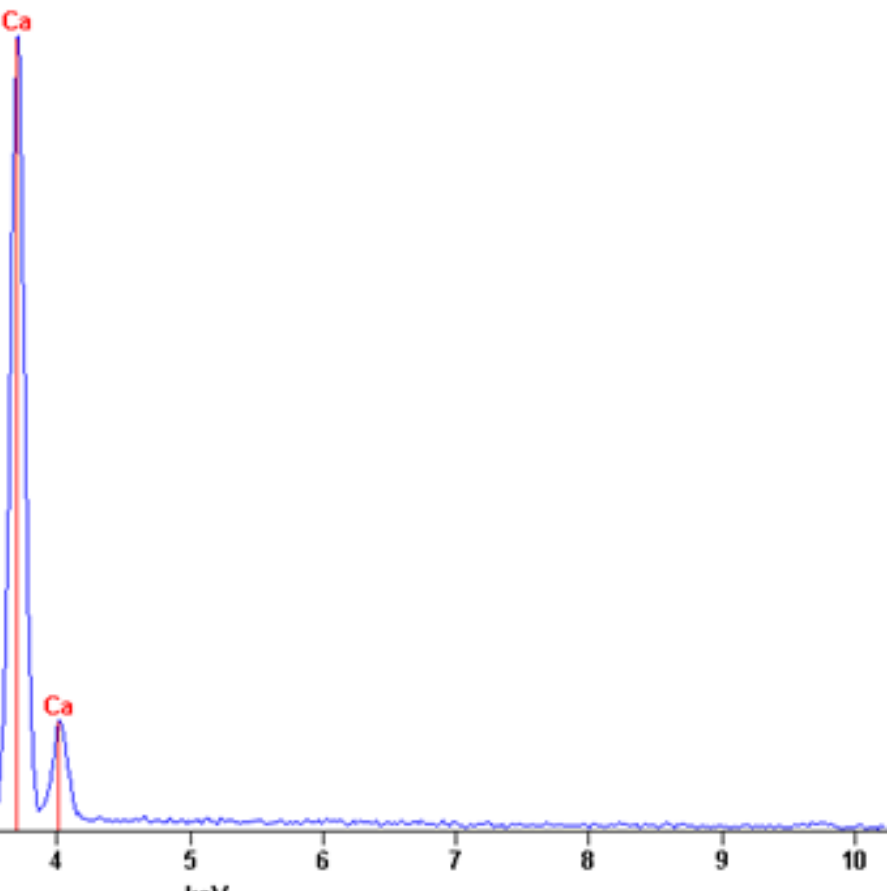

Figure 5. Chemical spectrum of needle fiber at the grassland site using SEM-EDS showing peaks of calcium (Ca), oxygen (O), and carbon $(\mathrm{C})$ consistent with the molar concentrations of calcite. The gold $(\mathrm{Au})$ peak is due to the sample coating.

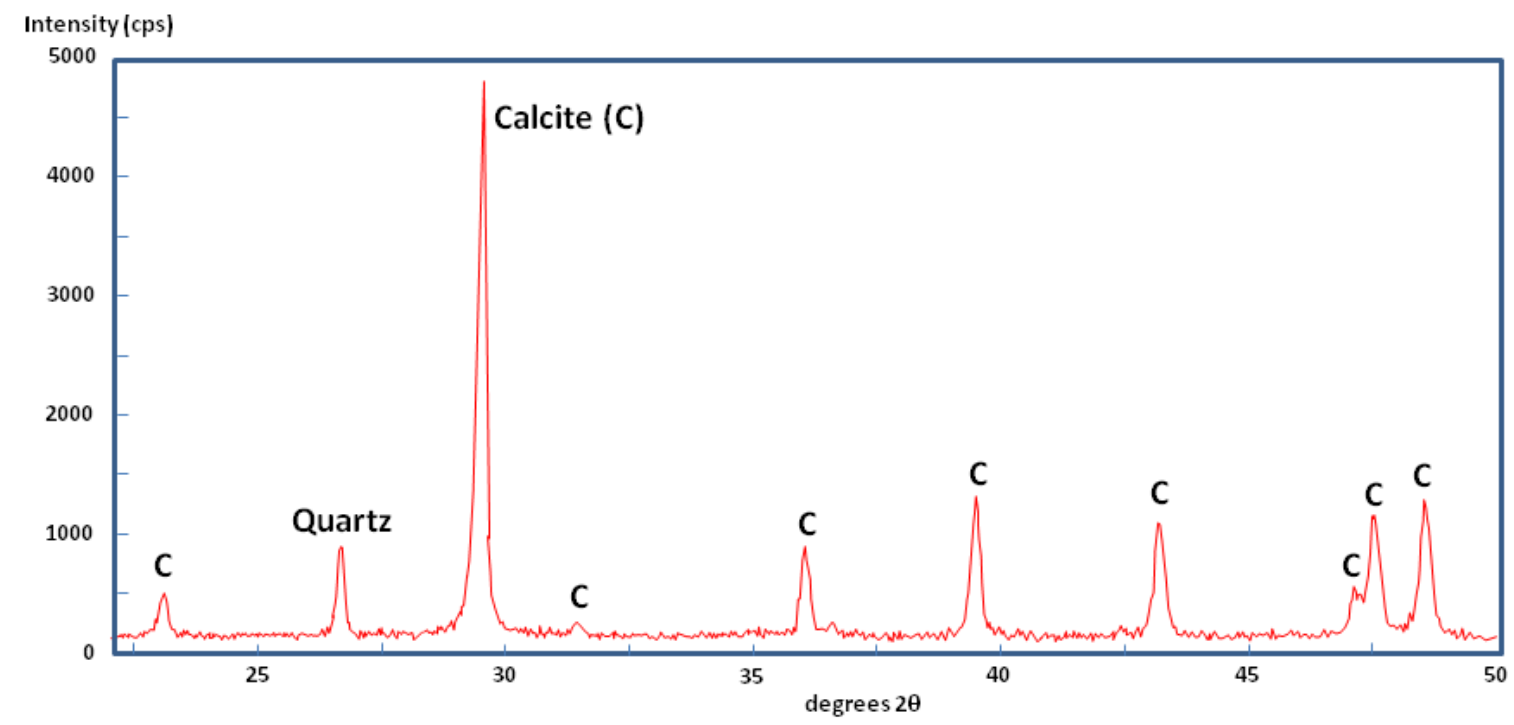

Figure 6. X-ray diffractogram of calcified roots and fungal hyphae coatings at the limestone forest site shown above in Figure 4C. 
Calcium oxalate whewellite $\left(\mathrm{CaC}_{2} \mathrm{O}_{4} \cdot \mathrm{H}_{2} \mathrm{O}\right)$ and weddellite $\left(\mathrm{CaC}_{2} \mathrm{O}_{4} \cdot 2 \mathrm{H}_{2} \mathrm{O}\right)$ are organic minerals occurring in various biological and geological environments. They are reported to be important for carbonate formation by microorganisms (Verrecchia et al. 1990, 2006) and for trees (Cailleau et al. 2011). X-ray diffraction of our samples, however, did not reveal precursor calcium oxalate crystals. Previous XRD analyses of soils in the study area also have not revealed calcium oxalate (Kraimer and Monger 2005). To date, calcite is the only pedogenic carbonate mineral associated with microbial biomineralization found in the soil environment of the study ares. However, calcium oxalate is commonly observed within plant roots in the study area. These crystals have similar appearances to those shown in Durand et al. (2010, Figure 21).

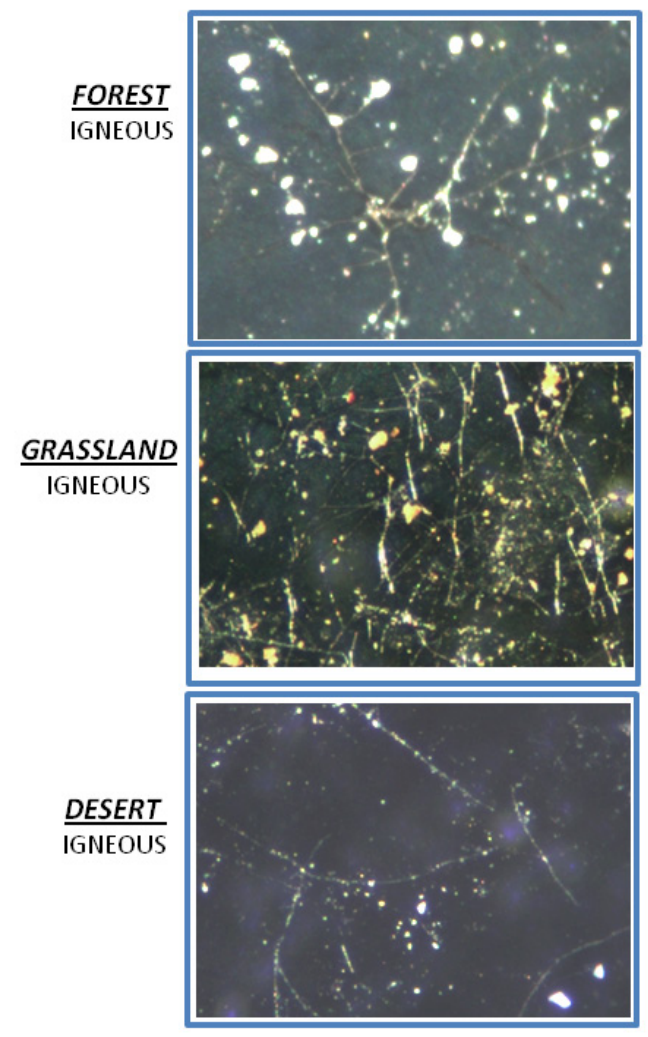

The density of hyphae and their calcification was very heterogeneous across the microscope slides. We could not accurately measure the amount of calcified hyphae on the microscope slides, but we were able to document the presence or absence of calcification (Table 3). These results revealed that the water control slides did not have calcified hyphae regardless of vegetation type or parent material, with the exception of one slide in the grassland igneous and one slide in the forest limestone. However, the bare microscope glass slides, which also served as a control, did contained calcified hyphae in both desert sites and at both forest sites, but not for the majority of grassland samples. When growth medium was supplied, calcification occurred at both desert sites, both grassland sites (with the exception of one sample), and both forest sites. This growth-

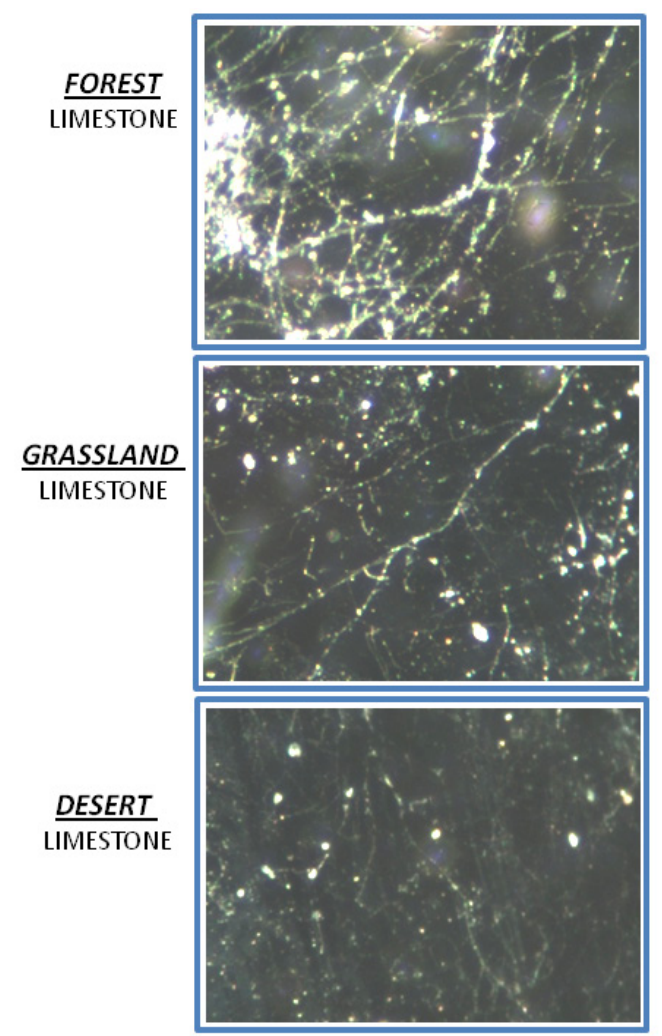

Figure 7. Photomicrographs of hyphae at each study site on cumulative slides January to February. Calcification occurs as linear white blocky zones along hyphae. (Photographs taken at 100x and crossed-polarized light). 
Table 3. Presence (+) or absence (-) of calcified hyphae on microscope slides attached to the nylon wicks of the apparatuses used to deliver liquid B4 medium to soil

\begin{tabular}{|c|c|c|c|c|c|c|c|c|c|c|c|c|c|c|c|c|c|c|c|c|c|c|c|c|}
\hline \multirow{2}{*}{ Month } & \multicolumn{4}{|c|}{ Desert Igneous } & \multicolumn{4}{|c|}{ Desert Limestone } & \multicolumn{4}{|c|}{ Grassland Igneous } & \multicolumn{4}{|c|}{ Grassland Limestone } & \multicolumn{4}{|c|}{ Forest Igneous } & \multicolumn{4}{|c|}{ Forest Limestone } \\
\hline & Water ${ }^{\mathrm{a}}$ & Incrb & Cum $^{\circ}$ & Glass $^{d}$ & Water & Incr & Cum & Glass & Water & Incr & Cum & Glass & Water & Incr & Cum & Glass & Water & Incr & Cum & Glass & Water & Incr & Cum & Glass \\
\hline JAN & & & + & & & & + & & & & + & & & & + & & & & + & & & & + & \\
\hline FEB & & & + & & & + & + & & & + & + & & & + & + & & & + & + & & & + & + & \\
\hline MAR & - & & + & + & - & + & + & + & - & + & + & + & - & + & + & - & - & + & + & + & - & + & + & + \\
\hline APR & - & + & + & + & - & - & + & + & - & + & + & $n f^{e}$ & - & - & + & + & - & + & + & nf & - & + & + & + \\
\hline MAY & - & + & + & + & - & + & + & + & - & + & + & - & $\mathrm{nf}$ & + & + & - & - & $n f$ & + & + & $\mathrm{nf}$ & + & + & + \\
\hline JUN & - & + & + & + & - & - & + & + & + & + & + & - & nf & + & + & - & - & + & + & + & + & + & + & + \\
\hline JUL & & + & & & & + & & & & + & & & & + & & & & + & & & & + & & \\
\hline
\end{tabular}

a "Water" apparatuses were filled with water instead of B4 medium to serve as a control.

b "Incr" apparatuses residing in soil for monthly increments of supplied with B4 medium.

c "Cum" apparatuses supplied with B4 medium placed in soil in December 2010 and harvested each month consecutively until July.

d "Glass" bare microscope slides that were buried and harvested at monthly intervals which also served as a control.

eSlides labeled "nf" were not found.

induced calcification occurred regardless of whether the slides were harvested at monthly increments or harvested at cumulative increments.

\subsection{Carbonate formed in fiberglass cloths}

Carbonate formed in fiberglass cloth samples during monthly and cumulative increments are shown in Table 4 and Figure 8 . Samples collected at monthly increments had an increase in April for the grassland limestone site and in May for the grassland igneous site. Carbonate formed in fiberglass at cumulative increments had a greater amount in the first month for three sites: desert igneous, forest limestone, and grassland limestone (Figure 8). Another peak can be seen at February for the grassland igneous site.

Total carbonate, which was obtained by summing the monthly values, is shown for February through June in Figure 9-the period when all sites have comparable measurements. The monthly-increment samples produced more carbonate than the cumulative-increment samples. Monthly-increment samples show more carbonate at the limestone sites than igneous site, but this trend was not found using the cumulative samples. Monthly-increment

Table 4. Amount of carbonate (expressed as inorganic carbon) generated in fiberglass cloth samples at each site collected at monthly and cumulative intervals

\begin{tabular}{|c|c|c|c|c|c|c|c|c|c|c|c|c|}
\hline \multirow{2}{*}{ Month } & \multicolumn{2}{|c|}{ Desert Igneous } & \multicolumn{2}{|c|}{ Desert Limestone } & \multicolumn{2}{|c|}{ Grassland Igneous } & \multicolumn{2}{|c|}{ Grassland Limestone } & \multicolumn{2}{|c|}{ Forest Igneous } & \multicolumn{2}{|c|}{ Forest Limestone } \\
\hline & Increm & Cumulative & Increm & Cumulative & Increm & Cumulative & Increm & Cumulative & Increm & Cumulative & Increm & Cumulative \\
\hline & $\% I^{a}$ & $\%$ IC & $\%$ IC & $\%$ IC & $\%$ IC & $\%$ IC & $\%$ IC & $\%$ IC & $\%$ IC & $\%$ IC & $\%$ IC & $\%$ IC \\
\hline JAN & & 0.85 & & & & 0.20 & & 0.63 & & 0.00 & & 1.56 \\
\hline FEB & 0.44 & 0.00 & 0.31 & 0.00 & 0.00 & 0.66 & 0.00 & 0.00 & 0.41 & 0.00 & 0.00 & 0.00 \\
\hline MAR & 0.04 & 0.23 & 0.11 & 0.13 & 0.19 & 0.07 & 0.61 & 0.00 & 0.25 & 0.00 & 0.57 & 0.00 \\
\hline APR & 0.00 & 0.21 & 0.23 & 0.24 & 0.35 & 0.00 & 1.12 & 0.00 & 0.34 & 0.05 & 0.28 & 0.13 \\
\hline MAY & 0.25 & 0.19 & 0.22 & 0.00 & 0.91 & 0.00 & 0.00 & 0.07 & $\mathrm{nf}$ & 0.00 & 0.27 & 0.00 \\
\hline JUN & 0.44 & 0.41 & 0.48 & 0.46 & 0.01 & 0.06 & 0.40 & 0.11 & 0.22 & 0.00 & 0.62 & 0.00 \\
\hline
\end{tabular}

a Weight percent inorganic carbon. 



Figure 8. Monthly amounts of carbonate formed in fiberglass cloths during the experiment.
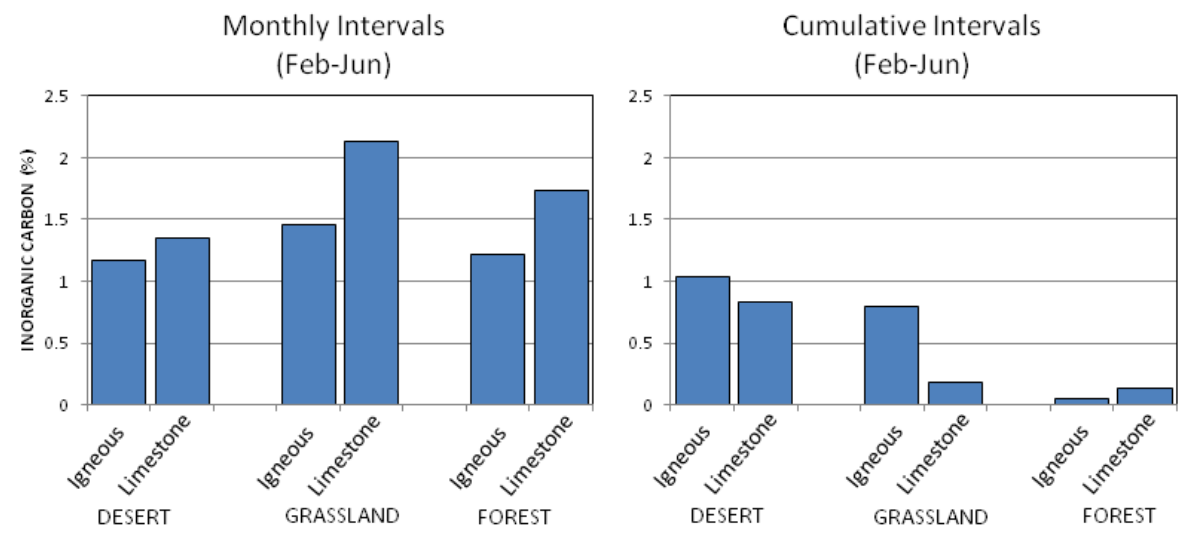

Figure 9. Total carbonate generated in the fiberglass cloths for the duration of the experiment (February to June 2011).

samples had more carbonate at the grassland sites, but the cumulative-increment samples had more carbonate at the desert site (Figure 9).

The reason that samples harvested at cumulative intervals have less total carbonate than those harvested at monthly intervals is unclear. Perhaps being in the soil for longer time periods caused carbonate that had formed earlier to dissolve later. If so, this result would suggest that carbonate biomineralization is a dynamic process that involves dissolution as well as precipitation. Short-term dissolution of carbonate has been documented elsewhere. Work by Smeck et al. (1968), for example, observed evidence for dynamic carbonate precipitation/dissolution in the Bk horizons of till-derived soils in western Ohio. They attributed the precipitation/dissolution cycles to seasonal water and leaching, which were followed by water deficit periods when carbonate precipitated. 


\subsection{Isotopic values}

With respect to carbon isotopes, as mentioned earlier, there was not enough carbonate generated in the fiberglass cloths to determine $\delta^{13} \mathrm{C}$ values. However, several natural values were determined on the vegetation, soil organic, and inorganic carbon from the study sites (Table 2). The desert igneous Btk horizon had a $\delta^{13} \mathrm{C}$ value of inorganic carbon of $-12 \%$ suggesting $0 \%$ $\mathrm{C}_{4}$ vegetation based on equation (2). The same horizon had a $\delta^{13} \mathrm{C}$ value of soil organic matter of $-21 \%$. This suggests $34 \% C_{4}$ vegetation based on equation (1). The desert igneous $\mathrm{Bkkm}$ organic value was $-16 \%$, indicating $82 \% \mathrm{C}_{4}$; the inorganic value was $-3 \%$, suggesting $64 \% \mathrm{C}_{4}$. The desert limestone Bkk1 had an organic $\delta^{13} \mathrm{C}$ value $-16 \%\left(82 \% \mathrm{C}_{4}\right)$; the inorganic value was $-7 \%$ 。 $\left(36 \% \mathrm{C}_{4}\right)$. The grassland igneous site $\mathrm{A}$ horizon had $\delta^{13} \mathrm{C}$ values of $-15 \%$ for the organic $\left(91 \% \mathrm{C}_{4}\right),-5 \%$ of the inorganic $\left(50 \% \mathrm{C}_{4}\right)$, and $-14 \%$ for the organic Btk $\left(100 \% \mathrm{C}_{4}\right)$, and $-1 \%$ ofor the inorganic Btk $\left(79 \% \mathrm{C}_{4}\right)$. The forest igneous A horizon had a value of $-22 \%$ 。 $\left(27 \% \mathrm{C}_{4}\right)$. The forest limestone site $\mathrm{A}$ horizon had $\delta^{13} \mathrm{C}$ values of $-25 \%$ for the organic $\left(0 \% \mathrm{C}_{4}\right),-13 \%$ for the inorganic $\left(0 \% \mathrm{C}_{4}\right)$, and $-23 \%$ of the organic Crk $\left(18 \% \mathrm{C}_{4}\right)$ and $-9 \%$ for the inorganic Crk $(21 \%$ $\left.\mathrm{C}_{4}\right)$. These data show that in the grassland and forest sites the $\delta^{13} \mathrm{C}$ values of both organic and inorganic carbon correspond well with the present dominant vegetation isotopic signatures. In the desert the $\delta^{13} \mathrm{C}$ in surface horizons carries the signature of the dominant present $\mathrm{C}_{3}$ vegetation, in contrast to the $\delta^{13} \mathrm{C}$ in Bkkm horizons that suggest the dominance of the $C_{4}$ vegetation. This could be explained by the fact that the area was formerly dominated by $\mathrm{C}_{4}$ grassland and later desertification caused the invasion of the area by $\mathrm{C}_{3}$ desert shrubs (Monger et al. 2009). Therefore $\delta^{13} \mathrm{C}$ signatures in the petrocalcic horizon are paleorelict features useful for explaining previous ecological conditions.

\section{Conclusions}

Traditionally, soil micromorphology studies of soil carbonate have been observational and based on thin section petrography, similar to mineralogy studies conducted by geologists (e.g., Drees and Wilding 1987; Khormali et al. 2006). Such observational studies have considered soil carbonate mainly in terms of inorganic chemistry. With the advent of SEM, progressively more attention has been given to a biogenic origin of soil carbonate, at least for a portion of soil carbonate. While this study builds on observational micromorphology, it could itself be categorized as experimental micropedology, in a manner similar to experimental pedology. As described by Hallsworth and Crawford (1965), "...it is now possible in pedology to put up a hypothesis and to submit it to the same kind of experimental investigation that has been responsible for the dramatic advances in other branches of science over the last fifty years." Based on an experimental micropedology approach, in addition to field observations, evidence from this study supports the following conclusions:

1. Microbial biomineralization is a widespread process in the deserts and grasslands of this study area and can extend into forests.

2. Calcification can be accelerated by adding liquid growth medium to soil in situ. But based on a substantial number of bare microscope slides inserted into soils, calcification by fungal hyphae is also a naturally occurring phenomenon that happens during a short time frame.

3. Indigenous microbial populations capable of biomineralizing carbonate in igneous soils when supplied with B4 liquid medium are not substantially different from neighboring population in limestone soils.

4. Amounts of carbonate formed in different bioclimatic zones are inconclusive. The samples harvested at monthly increments indicate grassland microbes formed more carbonate. However, samples harvested at cumulative increments indicate desert microbes made more carbonate. We can conclude, however, that samples harvested at monthly intervals 
produced more carbonate than samples harvested at cumulative intervals.

5. With regard to carbon isotopes, the amounts of biogenic carbonate formed in the fiberglass traps were too low to measure $\delta^{13} \mathrm{C}$ values. Therefore, no conclusions can be made about microbial fractionation of ${ }^{13} \mathrm{C}$ during biogenic precipitation. However, the natural values of the carbonates, which include the calcified microbes, may suggest a general conclusion. The A-horizons are more reflective of current vegetation than the subsoil horizons. Thus, these data support the notion that subsoil horizons have a "longer memory" than A horizons (Gerasimova and Lebedeva 2008).

\section{Acknowledgments}

This study was part of the research done during the first-author's sabbatical. Therefore, the senior author would like to express his gratitude to the Gorgan University of Agricultural Sciences and Natural Resources, Iran and New Mexico State University-Agricultural Experiment Station, USA. Support for this study was also provided by the Jornada Basin LTER program (National Science Foundation DEB-0080412).

\section{REFERENCES}

- Boquet E, Boronat A, Ramos-Cormenzana A. 1973. Production of calcite (calcium carbonate) crystals by soil bacteria is a general phenomenon. Nature 246:527-528.

- Boutton TW, Archer SR, Midwood AJ. 1999. Stable isotopes in ecosystem science: structure, function and dynamics of a subtropical savanna. Rapid Communications in Mass Spectrometry 13:1263-1277.

- Breecker DO, Sharp ZD, McFadden LD. 2009. Seasonal bias in the formation and stable isotopic composition of pedogenic carbonate in modern soils from central New Mexico, USA. Geological Society of America Bulletin 121:630-640. doi: 10.1130/B26413.1.

- Brewer R. 1964. Fabric and mineral analysis of soils. New York, NY: John Wiley \& Sons.

- Bullock P, Fedoroff N, Jongerius A, Stoops G, Tursina T, Babel U. 1985. Handbook for soil thin section description. Wolverhampton, UK: Waine Research Publications.

- Burford EP, Hillier S, Gadd GM. 2006. Biomineralization of fungal hyphae with calcite $\left(\mathrm{CaCO}_{3}\right)$ and calcium oxalate mono- and dihydrate in carboniferous limestone microcosms. Geomicrobiology Journal 23:599-611.

- Cailleau G, Braissant O, Verrecchia EP. 2011. Turning sunlight into stone: the oxalate-carbonate pathway in a tropical tree ecosystem. Biogeosciences Discuss. 8:1077-1108.

- Cerling TE. 1984. The stable isotopic composition of modern soil carbonate and its relationship to climate. Earth Planetary Science Letters 71:229-240.

- Chitale JD. 1986. Study of petrography and internal structures in calcretes of West Texas and New Mexico. Ph.D. diss. Lubbock, TX: Texas Tech Univ.

- Dick-Peddie WA. 1993. New Mexico vegetation: past, present, and future. Albuquerque, New Mexico: University of New Mexico Press.

- Drees LR, Wilding LP. 1987. Micromorphic record and interpretations of carbonate forms in the Rolling Plains of Texas. Geoderma 40:157-175.

- Durand N, Monger HC, Canti MG. 2010. Calcium carbonate features. In: Stoops G, Marcelino V, Mees F, editors. Interpretation of Micromorphological Features of Soils and Regoliths. Amsterdam: Elsevier. p. 149-194.

- FitzPatrick EA. 1972. Pedology-a systematic approach to soil science. New York, NY: Hafner Publishing Company, Inc.

- FitzPatrick EA. 1993. Soil microscopy and micromorphology. New York, NY: John Wiley \& Sons. 
- Folks JJ. 1975. Soil Survey of Santa Fe area, New Mexico. United States Department of Agriculture. Washington, DC: U.S. Govt. Printing Office.

- Gerasimova M, Lebedeva M. 2008. Contribution of micromorphology to classification of aridic soils. In: Kapur S, Mermut A, Stoops G, editors. New Trends in Soil Micromorphology. Berlin: Springer. p. 151-162.

- Gile LH, Ahrens RJ, Anderson SP. 2003. Supplement to the Desert Project Soil Monograph: Soils and landscapes of a desert region astride the Rio Grande Valley near Las Cruces, New Mexico. Volume III. Lincoln, NE: U.S. Department of Agriculture, Natural Resources Conservation Service, National Soil Survey Center. 374 p.

- Gile, LH, Hawley JW, Grossman RB. 1981. Soils and geomorphology in the Basin and Range area of southern New Mexico-Guidebook to the Desert Project. Memoir 39. Socorro: New Mexico Bureau of Mines and Mineral Resources.

- Gile LH, Peterson FF, Grossman RB. 1966. Morphological and genetic sequences of carbonate accumulation in desert soils. Soil Science 101:347-360.

- Goudie AS. 1996. Organic agency in calcrete development. J Arid Environ. 32:103-110.

- Guo Y, Amundson R, Gong P, Yu Q. 2006. Quantity and spatial variability of soil carbon in the conterminous United States. Soil Science Society of America Journal 70:590-600

- Hallsworth EG, Crawford DV. 1965. Experimental pedology. London: Butterworths.

- Hirmas DR, Amrhein C, Graham RC. 2010. Spatial and process-based modeling of soil inorganic carbon storage in an arid piedmont. Geoderma 154:486-494.

- Jones B. 1988. The influence of plants and microorganisms on diagenesis in caliche: example from the Pleistocene ironshore formation on Cayman Brac, British West Indies. Bull Can Petrol Geol. 36:191-201.

- Kahle CF. 1977. Origin of subaerial Holocene calcareous crust: Role of algae, fungi, and sparmicritisation. Sedimentology 24:413-435.

- Khormali F, Abtahi A, Stoops G. 2006. Micromorphology of calcitic features in highly calcareous soils of Fars Province, Southern Iran. Geoderma 132:31-46.

- Klappa CF. 1979. Calcified filaments in Quaternary calcretes: Organo-mineral interactions in the subaerial vadose environment. J Sediment. Petrol. 49:955-968.

- Kraimer, RA, Monger HC, Steiner RL. 2005. Mineralogical distinctions of carbonates in desert soils. Soil Science Society of America Journal. 69:1773-1781.
- Krumbein WE. 1968. Geomicrobiology and geochemistry of the "Nari-Lime-Crust" (Israel). In: Muller G, Friedman GM, editors. Recent Developments in Carbonate Sedimentology in Central Europe. Berlin: SpringerVerlag. p. 138-147.

- Kubiëna WL. 1970. Micromorphological features of soil geography. New Brunswick, New Jersey: Rutgers University Press.

- Marion GM, Schlesinger WH, Fonteyn PJ. 1985. CALDEP: A regional model for soil $\mathrm{CaCO}_{3}$ (caliche) deposition in southwestern deserts. Soil Science 139:468-481.

- Marion GM, Verburg PSJ, Stevenson B, Arnone III JA. 2008. Biogeochemical cycling in a Mojave Desert soil. Soil Science Society of America Journal 72:1815-1823.

- Monger HC, Adams HP. 1996. Micromorphology of calcite-silica deposits, Yucca Mountain, Nevada. Soil Science Society of America Journal 60:519-530.

- Monger HC, Cole DR, Buck BJ, Gallegos RA. 2009. Scale and the isotopic record of $\mathrm{C}_{4}$ plants in pedogenic carbonate: from the biome to the rhizosphere. Ecology 90(6):1498-1511.

- Monger HC, Daugherty LA, Lindeman WC. 1991. Microbial precipitation of pedogenic calcite. Geology, 19:997-1000.

- Monger HC, Southard RJ, Boettinger JL. 2011. Classification of Soils. Aridisols. In: Huang PM, Li Y, Sumner ME, editors. Handbook of Soil Science. 2nd Edition. Boca Raton: CRC Press. p. 33-1 to 34-1.

- New Mexico Bureau of Geology and Mineral Resources. 2003. Geologic Map of New Mexico, 1:500,000. Socorro: New Mexico Bureau of Geology and Mineral Resources.

- Peterson FF. 1981. Landforms of the Basin \& Range province defined for soil survey. Technical Bulletin 28. Nevada Agricultural Experiment Station, University of Nevada, Reno.

- Phillips SE, Milnes AR, Foster RC. 1987. Calcified filaments: An example of biological influences in the formation of calcretes in South Australia. Australian Journal of Soil Research 25:405-428.

- Quade J, Cater JML, Ojha RP, Adam J, Harrison TM. 1995. Late Miocene environmental change in Nepal and the northern Indian subcontinent: Stable isotopic evidence from paleosols. Geological Society of American Bulletin 107:1381-1397.

- Schlesinger WH, Belnap J, Marion G. 2009. On carbon sequestration in desert ecosystems. Global Change Biology 15:1488-1490. doi: 10.1111/j.13652486.2008.01763.x. 
- Schoeneberger PJ, Wysocki DA, Benham EC, Soil Survey Staff. 2012. Field book for describing and sampling soils, Version 3.0. Lincoln, NE: Natural Resources Conservation Service, National Soil Survey Center.

- Seager WR, Hawley JW, Kottlowski FE, Kelley SA. 1987. Geologic Map 57. Socorro: New Mexico Bureau of Mines and Mineral Resources.

- Smeck N, Wilding LP, Holowaychuk N. 1968. Genesis of argillic horizons in Celina and Morely soils of western Ohio. Soil Science of America Journal 32:550-556.

- Soil Survey Staff. 1999. Soil taxonomy-a basic system of soil classification for making and interpreting soil surveys. Handbook 436. U.S. Department of Agriculture, Soil Conservation Service. U.S. Government Printing Office.

- Stoops G. 2003. Guidelines for analysis and description of soil and regolith thin sections. Madison, Wisconsin, USA: Soil Science Society of America, Inc.

- Verrecchia EP. 1990. Lithodiagenetic implications of the calcium oxalate-carbonate biogeochemical cycle in semiarid calcretes, Nazareth, Israel. Geomicrobiology Journal 8:89-101.

- Verrecchia EP, Dumont JL, Rolko KE. 1990. Do fungi building limestones exist in semi-arid regions? Naturwissenschaften 77:584-586.

- Verrecchia EP, Verrecchia KE. 1994. Needle-fiber calcite: a critical review and a proposed classification. Journal of Sedimentary Research 64:650-664.

- Verrecchia EP, Braissant O, Cailleau G. 2006. The oxalate-carbonate pathway in soil carbon storage: the role of fungi and oxalotrophic bacteria. In: Gadd GM, editor. Fungi in Biogeochemical Cycles. Cambridge: Cambridge University Press. p. 289-310.

- Weems SL, Monger HC. 2012. Banded vegetationdune development during the Medieval Warm Period and 20th century, Chihuahuan Desert, New Mexico, USA. Ecosphere 3, art21.

-Wilding LP, Drees LR, Nordt LC. 2001. Spatial variability: enhancing the mean estimate of organic and inorganic carbon in a sampling unit. In: Lal R, Kimble JM, Follett RF, Stewart BA, editors. Assessment Methods for Soil Carbon. Boca Raton, FL: Lewis Publishers. p. 69-86.

- Wilding LP, Drees LR, Woodruffs CM. 1997. Mineralogy and microfabrics of limestone soils on stepped landscapes in Central Texas. In: Shoba S, Gerasimova M, Miedema $\mathrm{R}$, editors. Soil Micromorphology: studies on soil diversity, diagnostics, and dynamics. Proceedings of the $X$ International Working Meeting on Soil Micromorphology; 1996 July 8-13; Moscow, Russia. Wageningen, The Netherlands: Printing Service Centre Van Gils B.V. for Sub-Commission of Soil Micromorphology, International Society of Soil Science. p. 204-218. 